\title{
Can sediment data be used to predict alkalinity and base cation chemistry of surface waters?
}

\author{
S. Begum ${ }^{1 *}{ }^{3}$, C.J.McClean ${ }^{1}$, M.S. Cresser ${ }^{1} \&$ N. Breward ${ }^{2}$ \\ ${ }^{1}$ Environment Department, The University of York, Heslington, York UK \& ${ }^{2}$ British \\ Geological Survey, Keyworth, Nottingham NG12 5GG \\ ${ }^{3}$ Environmental Sciences Department, Fatima Jinnah Women University, Rawalpindi, \\ Pakistan \\ ${ }^{*}$ Corresponding author. \\ E-mail address: sb641@york.ac.uk
}

\begin{abstract}
We hypothesise that stream sediment elemental composition can predict mean and minimum concentrations of alkalinity, $\mathrm{Ca}$ and $\mathrm{Mg}$ in the river water throughout a river network. We tested this hypothesis for the River Derwent catchment in North Yorkshire, England, by using 6 years of water chemistry data from the Environment Agency and a digital elevation model to flow pathweight British Geological Survey (BGS) sediment element concentration data. The predictive models for mean concentrations were excellent for $\mathrm{Ca}$ and alkalinity, but less good for $\mathrm{Mg}$, and did not require land use data inputs as stream water sediment composition seems to reflect all aspects of the riparian zone soil system. Predictive model forms were linear. Attempts to predict minimum values for $\mathrm{Ca}$ and alkalinity also were less satisfactory. This probably is due to variations in hydrological response times to individual precipitation events across the catchment.
\end{abstract}

Key words: Alkalinity, calcium, magnesium, river sediment, predict, flow accumulation, River Derwent

\section{Introduction}

One positive aspect of concerns over acid deposition impacts upon terrestrial and aquatic ecosystems was the interest stimulated in the quantification of weathering rates and alkalinity generation within soil systems. In acidification-sensitive drainage basins, acid neutralization capacity of river waters approximately equates to Gran 
alkalinity (Neal, 2001). Consequently there is a need for reliable methods that can predict the amounts of alkalinity generated in soils and, potentially, transferable to surface waters. In the present study we have tested the hypothesis that alkalinity is predictable from sediment total Ca or Ca plus Mg concentrations as such data are readily available in many countries from past geological surveys. Alkalinity fluxes determine critical loads of acidity for freshwaters and soils. A robust and verifiable method for predicting alkalinity generation over regional and national scales therefore should be extremely useful in planning strategies for integrated catchment management and managing acid deposition effects (Cresser et al., 2006). Moreover, in the context of the ameliorative role of soil C storage in climate change, currently there is much interest in losses of both inorganic and organic carbon from soils.

Biochemical processes in the terrestrial environment strongly influence the hydrochemical response of small catchments, as stream water is largely made up of drainage from soils (Moldan and Cerny, 1994). A recent study of spatial and seasonal variations in water chemistry across North West England very effectively highlighted the diversity of factors influencing water chemical quality at regional scales (Rothwell et al., 2010). In spite of this complexity, numerous successful hydro-chemical models have been developed over recent decades for predicting, for individual streams, the temporal changes in water chemical quality during and following precipitation events (e.g. Christopherson et al., 1982; Gherini et al., 1985; Nikolaidis et al.,1988; Christopherson et al., 1994). Process-based models may be applied over longer time scales too (Cosby et al., 1985; Whitehead et al., 1988), although care is then needed to ensure that the model encompasses all key parameters driving water chemistry if extrapolation is made significantly beyond the calibration period. Cresser et al. (2000) pointed out, however, that most such models are not transferrable between catchments, which limits their use at regional or national scales. More recently, in a review of benchmarks for ecological and water quality assessments, Hawkins et al. (2010) highlighted the dominance of site-specific modelling approaches, and the crucial importance of better characterization of freshwater environments at a more general level.

Generation of site-specific models based upon data collection is generally prohibitively expensive for regional or national scale use. Billett and Cresser (1992) therefore aspired to be able to predict spatial and temporal variations in water chemistry over a regional scale from readily available soil maps and associated, 
already published, soil chemical data. They postulated that it should be possible to predict stream water chemistry under high and low flow conditions from the characteristics of the surface and sub-surface soils in the riparian zone. They further hypothesised that the relative proportions of different soil types immediately adjacent to streams in the Scottish highlands should affect stream water chemistry far more than the total proportional coverage of soil types in each stream's catchment. They therefore used catchment topography to predict flow paths for each catchment to work out the relative proportions of precipitation falling on the catchment likely to drain through each riparian zone soil type. This provided an appropriate flow path weighting for each soil type in their predictive model. Using \% Ca saturation of the cation exchange capacity (CEC) for surface and sub-surface soil horizons, flow pathweighted as described above, they obtained excellent predictive relationships for mean and maximum (base flow) Ca concentrations (Billett and Cresser, 1992). However, prediction of minimum Ca concentration for their 10 upland catchments was appreciably poorer. The model later became known as the Aberdeen Soil Horizon (ASH) model (Cresser et al., 2000).

The above results were based upon detailed soil surveys and chemical analyses for 10 upland moorland catchments(Billett and Cresser, 1992). There was no agricultural land use other than rough grazing, and no, or minimal, forestry in any of the catchments. Hooper et al. (1998) later demonstrated the importance of riparian water at the Panola Mountain Research Watershed, Georgia, to base flow and storm flow chemistry, consistent with the concepts of the ASH model.

Johnson et al. (1997) showed that riparian zone soils and land use strongly influenced stream water chemistry in summer at Saginaw Bay in the USA. Land use was not incorporated in the ASH model, because soil management practices associated with diverse types of land use and soil management would cause appropriate changes to the Ca saturation of the CEC of upper and lower soil horizons, so should be incorporated automatically within the model.

ASH utilised the flow path-weighted cation exchange chemistry of the mineral sub-soil (B/C horizon) to predict the base flow chemistry, and that of the organic-rich surface horizons ( $\mathrm{O}$ and A horizons) to predict chemistry at high-flows. However, the need for reliable high-resolution soil maps was subsequently found to severely restrict the widespread applicability of the ASH model (Cresser et al., 2000). It was modified therefore by making it geology-based (G-BASH) for predictions of Gran alkalinity 
and base cation concentrations in stream waters, the underpinning concept being that soil parent material and topography in combination should be a reliable surrogate for soil type and chemistry (Cresser et al., 2000). The down side of basing predictions upon underlying geology was that it was then essential to incorporate riparian zone land cover type into the G-BASH model because of its potential impact upon the chemistry of riparian zone soils. The predictive equations that successfully emerged for alkalinity and base cation concentrations were based primarily upon flow pathweighted bedrock geological composition and proportions of arable land and improved grazing in the riparian zone (Cresser et al., 2000).

The G-BASH model was subsequently modified and extended with reasonable success to predict Gran alkalinity across the whole River Dee Catchment in North East Scotland using digitized geological maps, published rock chemical composition data, and a simple hydrological flow path model in a geographical information system (Smart et al., 2001). Only the rock chemistry was flow path-weighted because of resolution constraints of the GIS for land cover. It was hoped that the G-BASH model subsequently would be transferable to other regions, though so far this has happened, and only after modification, for north west England.

Acid deposition reduces alkalinity, but landscape characteristics moderate the pollution impacts on water chemical quality (Norton, 1980; Soulsby and Reynolds, 1995). It has long been recognized that the sensitivity of the streams to acidification is predictable from the underlying bedrock geology (Norton, 1980; Bricker and Rice, 1989). In Japan, Asano and Uchida (2005) reported that acid neutralization in soils and/or permeable bedrock was important in the neutralization of hill slope discharge for two hydrologically well-defined, steep, granitic drainage basins in the Tanakami Mountains. Extending the application of G-BASH for predicting alkalinity from north east Scotland to north west England, Cresser et al. (2006) found it was essential to take into account both the extent to which alkalinity had been used up in countering the effects of acid deposition as well as the greater dilution in a region where runoff was higher.

With recent technological advances, especially the improved availability and affordability of Geographic Information Systems (GIS), many GIS-based surface and subsurface water models have been applied in resource and water discharge management (e.g. Djokic and Maidment, 1993; Goodchild et al., 1993; Ross and Tara, 1993; Merchant, 1994; Smith and Vidmar, 1994; Cowen et al., 1995; Greene and 
Cruise, 1995; Poiani and Bedford, 1995; Shamsi, 1996; Bennett, 1997; USEPA 2001). Integration of conceptual models with best available technology to overcome the barriers that hinder their use has been strongly recommended (Coroza et al., 1997; Sui and Maggio, 1999).

A potentially invaluable and readily available data resource that does not appear to have been considered in the context of predictive models for stream water chemical quality, even at the individual catchment level, is the British Geological Survey river sediment data. These data are in the public domain as a series of 17 regional geochemistry atlases (e.g. BGS, 1996) and as the NERC G-BASE data resource. Sediment composition, like stream water chemical composition, depends upon riparian zone soils and geology and land use adjacent to, and upstream of, the sampling point, so should be an integrating parameter for all their effects. Sediment composition is known to affect heavy metal concentrations present in waters as a result of prior mining activities (Aston et al., 1974). Plant and Moore (1979) noted that appropriately sampled stream sediments should approximate to a composite sample of the weathering products upstream. The objective of the present research is to test the idea that such sediment data can be used to spatially model stream water chemistry. This assumption is made on the basis that sediment composition should directly reflect riparian zone soil characteristics. If successful, such a relatively simple tool should have many benefits to planners, particularly in terms of assessment and management of catchment systems at regional and national scales. Our study is a preliminary assessment of the potential use of BGS sediment data for the River Derwent in North Yorkshire, England, for assessing the spatial and temporal variations in alkalinity, $\mathrm{Ca}$, and $\mathrm{Mg}$ concentrations in river water. It is hypothesised that it will be possible to predict mean and minimum concentrations of these determinants just from flow path-weighted sediment Ca and Mg concentrations, with no reference to land use.

\section{Site description, data and methodology}

\subsection{Study Area}

The River Derwent in North Yorkshire, England, is used for water abstraction, leisure and sporting activities, and effluent disposal, and its catchment contains several nature reserves. It is $115 \mathrm{~km}$ long and drains $2057 \mathrm{~km}^{2}$ (Neal et al. 1998). In the Yorkshire 
area, its catchment is a significant surface and groundwater resource (NRA, 1992). Although considered a clean river with water quality of class 1a (very good) to class 1b (good) based on chemical indices, it has a poorer biological quality rating, the poorest water occurring in the lowland stretches at the southern end of the River (NRA, 1992).

The drainage basin is predominantly rural, with little industry other than agriculture. The headwater areas are mainly heather/grass moorland, bracken, and coniferous woodland (20\%), whereas the lower areas are predominantly arable (40\% is mainly cropped with wheat and winter- and spring-barley) along with agricultural pasture and meadowlands (25\%) and forestry (5\%) (Neal et al., 1998). The catchment has received significant deposition of acidic oxide pollutants from the atmosphere in the recent past (Smith et al., 1997).

As shown in Fig. 1, the area is underlain by Cretaceous Chalk, Jurassic sandstone, limestone and clays, and Triassic sandstones and mudstones (Neal et al., 1998), overlain by recent and Pleistocene alluvium ranging from clay to gravel.

\subsection{Data}

Water chemical data are from the Environment Agency for eight sites along River Derwent, namely Forge Valley, Sherburn, Yedingham, Malton, Low Hutton, Howsham Bridge, Sutton Lock and Derwent Bridge (Fig. 1), covering January 1998 to January 2004 at approximately monthly intervals. Table 1 shows the $\mathrm{Ca}, \mathrm{Mg}$, and alkalinity mean values and ranges for each EA sampling site.

Stream sediment data for 851 samples in the drainage basin are from the British Geological Survey. The ranges, means and standard deviations for $\mathrm{Ca} \%$ and $\mathrm{Mg} \%$ of the data are shown in Table 2. The methods used for stream sediment sampling are fully described in BGS (1996), and are those now recommended as international standards for geochemical mapping (Darnley et al., 1995); they were based upon earlier work by Plant and Moore (1979). Samples of active sediments were collected, upstream, if necessary, of any identifiable potential source of local contamination such as housing, industry, or road or track crossings. A layer of oxidised material at the surface was removed prior to sampling the sediment, which then was wet-screened in the field using a minimum quantity of water to collect sediment finer than $150 \mu \mathrm{m}$ until ca. $100 \mathrm{~g}$ of material was obtained. Following preliminary air drying, the samples were freeze-dried at a field laboratory. A sediment 
subsample of ca. $50 \mathrm{~g}$, obtained by cone-and-quartering, was ball milled and a further sub-sample of the finely ground material then analysed as a powder by direct reading DC arc atomic emission spectrometry. Details of the analytical methodology and quality control procedures are given elsewhere (BGS, 1996).

\subsection{GIS analysis}

A Digital Elevation Model (DEM) of the area enclosing the River Derwent drainage basin (50 m x $50 \mathrm{~m}$ grid) was produced from the Ordnance Survey PANORAMA dataset based upon 1:50000 contour data. This was used in the GIS to quantify the spatial relationships between stream water chemical variables (alkalinity, Ca, and Mg concentrations) at the eight EA river water sampling stations and upstream drainagewater pathway-weighted sediment sample data (sediment Ca and Mg concentrations). Thus sediment elemental composition data from the British Geological Survey (BGS) were used in ArcGIS to provide spatial distributions of the $\mathrm{Ca}$ and $\mathrm{Mg}$ concentrations in sediment that were deemed likely to influence the temporal and spatial variations in stream water alkalinity, $\mathrm{Ca}$, and $\mathrm{Mg}$ concentrations.

The method used simple algorithms for terrain analysis of gridded-DEM available in most GIS software. These allowed an indication of surface water flow directions to be calculated. Surfaces of flow directions were then used to calculate the upstream contributing area for each DEM grid cell (flow accumulation). Flow accumulation is highest along stream channels and decreases rapidly away from channels. Therefore by using an arbitrary threshold of upstream contributing area, a stream network representation was obtained from the DEM. Sediment sampling point $\mathrm{Ca}$ and $\mathrm{Mg}$ data were attached to their nearest stream network cell, so that sediment data matched the topography representation of the DEM. Once sediment sampling points were located on the gridded representation of the stream network, each cell on the stream network was then allocated to the closest sediment sampling point on the network. This was calculated using standard GIS cost surface analysis, where stream cells had very low cost in comparison to non-stream cells.

Having allocated segments of the stream network to their closest sediment sampling point, the furthest downstream cell of segments allocated to each sediment sampling point was found. Using these as pour-points, once again, standard GIS algorithms for finding watersheds from DEM data were used to find the watershed 
upstream of each of these points. These areas represented "sub-catchments" corresponding to each sampling point.

The Ca or Mg concentration in stream water was modelled for all sampling points on the stream network by finding the watershed for each of these points. These watersheds were overlain with the watershed layers for sediment sampling points. Taking the sum of the appropriate element values for these overlaid areas and dividing by the number of cells in those areas gave "flow-weighted" sediment Ca or Mg values.

For the eight sites along the River Derwent, relationships were then examined between mean and minimum $\mathrm{Ca}, \mathrm{Mg}$, and alkalinity concentrations in water and drainage flow path-weighted sediment base cation metal concentrations. For Ca and alkalinity we looked at relationships for the means of the three lowest concentrations in river water to compare with use of single minimum concentrations for each EA site.

Forge Valley is quite different from the other study sites within the River Derwent catchment because of a sea cut, where most of the water is diverted to the North Sea in the interests of flood protection down-stream. Therefore, because its contribution to water quality downstream is small, it was treated throughout as a small independent catchment. Subsequently relationships were investigated with and without Forge Valley data.

\section{Results}

\subsection{Predicting alkalinity from sediment $\mathrm{Ca}$ and $\mathrm{Mg}$}

Mean alkalinity values at the water sampling sites were plotted against flow-pathweighted Ca (\%) in sediment (Fig. 2). The $\mathrm{R}^{2}$ - values for simple linear regressions are 0.989 with Forge Valley and 0.968 without. The significance of coefficients and intercepts of regression equations is shown in Table 3. Inclusion of Forge Valley data had an insignificant effect upon slope or intercept (Table 3).

Both $\mathrm{Ca}\left(\mathrm{HCO}_{3}\right)_{2}$ and $\mathrm{Mg}\left(\mathrm{HCO}_{3}\right)_{2}$ are likely to be major contributors to alkalinity within the River Derwent because of the calcareous geology of the area, so it was decided to test whether adding $\mathrm{Ca}$ and $\mathrm{Mg}$ concentrations of the sediment on a moles of charge basis improved the correlation strength. This basis was used to allow 
summation of different element concentrations and because $\mathrm{HCO}_{3}{ }^{-}$will be predominantly balanced by $\mathrm{Ca}^{2+}$ and $\mathrm{Mg}^{2+}$ in water samples. Plotting river water alkalinity against sediment $\mathrm{Ca}+\mathrm{Mg}$ (as $\mathrm{mmol}_{\mathrm{C}} / \mathrm{kg}$ ) again produced highly significant linear correlations regardless of whether Forge Valley data were included or excluded (Fig. 2 and Table 3). Changing the linear equation without Forge Valley data to a $2^{\text {nd }}$ order polynomial improved the $\mathrm{R}^{2}$ value to 0.992 , but is not easy to justify, because adding the Forge Valley data did not significantly change either the slope or the intercept of the simpler linear regression line (Fig. 2). The Forge Valley data would not fit on the extrapolated polynomial line.

\subsection{Predicting mean Ca or $\mathrm{Mg}$ concentrations from sediment \% Ca or $\mathrm{Mg}$}

The mean Ca concentration in river water was strongly correlated with flow-path weighted sediment Ca concentration $\left(\mathrm{R}^{2}=0.942\right.$ for a linear trend line when the Forge Valley data were included, Fig. 3 and Table 3).

A $2^{\text {nd }}$ order polynomial equation best described the relationship between river water mean $\mathrm{Mg}$ concentration and flow path-weighted sediment \% $\mathrm{Mg}$, giving an $\mathrm{R}^{2}$ value of 0.964 . This possibly is justifiable to a limited extent on the grounds that there would be a significant input of $\mathrm{Mg}$ from the atmosphere even if there was no $\mathrm{Mg}$ in sediment, because of the maritime climate of the UK, but the simpler linear regression is also reasonable fit (Fig. 3 and Table 3).

\subsection{Predicting lowest $\mathrm{Ca}$ and alkalinity concentrations from sediment \% Ca}

Figure 4 shows the correlations for scatter plots for the means of 3 lowest Ca concentrations in river water against flow path-weighted sediment $\mathrm{Ca}$, both including and excluding the Forge Valley data. The linear equations gave $\mathrm{R}^{2}$ values of 0.729 and 0.935 , respectively (Table 3), but with negative Ca concentrations in the water at very low sediment Ca concentrations.

The relationships between means of three lowest alkalinity values for each site and flow path-weighted sediment Ca concentration were slightly weaker than those for lowest Ca concentrations in water, regardless of whether or not Forge Valley data were included $\left(\mathrm{R}^{2} \quad 0.675\right.$ and 0.877 respectively, Table 3). Correlations were even less significant for discrete minimum values for each site. 


\section{Discussion}

\subsection{Predicting alkalinity from sediment $\mathrm{Ca}$ and $\mathrm{Mg}$}

The very high $\mathrm{R}^{2}$ values of above 0.9 for predictions of mean alkalinity values at the water sampling sites using flow-path-weighted Ca (\%) in sediment indicate that this single variable seems to be an excellent predictor for water mean alkalinity. By including data for Forge Valley as an independent catchment, the calibration range was significantly extended by the presence of a catchment highly dominated by heather moorland and mainly coniferous woodland. However, the slopes and intercepts of the regression plots in Fig. 2 differ very little (Table 3); therefore the Forge Valley catchment could be regarded as a validation catchment for the model obtained with Forge Valley excluded. There is no evidence from regression diagnostics that Forge Valley (at the lower end of both the response and predictor variable range) influences the regression model unduly.

Plotting river water alkalinity against sediment $\mathrm{Ca}+\mathrm{Mg}\left(\right.$ as $\left.\mathrm{mmol}_{\mathrm{C}} / \mathrm{kg}\right)$ did not improve the fit of model predictions to observations, regardless of whether Forge Valley data were included or excluded. Although both $\mathrm{Ca}\left(\mathrm{HCO}_{3}\right)_{2}$ and $\mathrm{Mg}\left(\mathrm{HCO}_{3}\right)_{2}$ will contribute to alkalinity within the river, some $\mathrm{Mg}$ emanating from the riparian zone soils will undoubtedly be of maritime origins. Cresser et al. (2000) found that their equations for predicting river water $\mathrm{Mg}$ concentrations in River Dee subcatchments in northeastern Scotland were significantly improved when chloride concentration was included as one of the predictive variables in their model. Green et al. (2008) have shown that road salting can significantly increase the $\mathrm{pH}$ of soils lying between roads and parallel river systems. In future work it may be necessary therefore to consider the possible contribution that road salting may make to equations for predicting alkalinity if $\mathrm{Mg}$ sediment data are included, as road salt in the UK generally contains substantial amounts of $\mathrm{Mg}$ and often $\mathrm{Ca}$ as gypsum too.

\subsection{Predicting mean Ca or Mg concentrations from sediment \% Ca or $\mathrm{Mg}$}

The strong linear correlation between mean Ca concentration in river water and flow path-weighted sediment Ca concentration suggests that it should be feasible to predict spatial variations in mean Ca concentrations throughout catchments.

Although a $2^{\text {nd }}$ order polynomial equation best described the relationship between river water $\mathrm{Mg}$ concentration and flow path-weighted sediment \% $\mathrm{Mg}$, 
giving an $\mathrm{R}^{2}$ value of 0.964 , simple linear regression provides a useful predictive relationship. It is highly likely that road salting/road runoff would substantially enhance the river water $\mathrm{Mg}$ concentration at some sites. The Sherburn and Yedingham sites gave the highest river water mean Mg concentrations (Table 1), and these are the sites where road runoff would exert the greatest effect because the sea cut reduces dilution from less contaminated and more rural upland areas.

\subsection{Prediction lowest Ca and alkalinity concentrations from sediment \% Ca}

Although the linear regression model based upon means of 3 lowest Ca concentrations in river water against flow path-weighted sediment $\mathrm{Ca}$, excluding the Forge valley site, is good, it is probably not yet adequate for predictive purposes without more calibration data. This is because of the negative intercept and because of the poor $\mathrm{R}^{2}$ value when Forge Valley data are included. Correlations were even poorer if simple single lowest concentration values were used rather than means of the three lowest values for each water sampling site (plots not shown). Clearly more data are needed before an appropriate predictive model is found, and this might also overcome the problem of negative intercepts.

With hindsight, the relatively poor relationships between means of three lowest alkalinity values for each site and flow path-weighted sediment Ca concentrations are probably to be expected. Alkalinity minima correspond to high or highest discharge conditions (Wade et al., 1999), which are likely to be attained at different times during storms across the catchment and along its length. They will also depend upon the spatial variations in the acidity of near-surface soils. Such variations are caused by variability of natural soil acidification processes coupled with acid deposition impacts, as soil acidity of both organic acid and mineral acid origins will be neutralized to some extent by in-situ alkalinity generation (Cresser et al., 2006). Therefore substantial variations in alkalinity around minimum values are to be expected. Research by Tetzlaff et al. (2007) using fine resolution Gran alkalinity time series data over a hydrological year demonstrated, for the Feugh catchment in Scotland, that there were diverse and subtle changes in stream-water chemistry over the year. When attempting to model stream-water Gran alkalinity at different spatial scales and under different 
hydrological conditions using end member mixing analysis (EMMA), Wade et al. (1999) commented on the problems caused by the very limited amount of high discharge data when rivers were sampled only monthly.

\subsection{Conclusions}

The results of this preliminary study strongly support the hypothesis that stream water sediment elemental composition data are useful for prediction of mean concentrations of alkalinity, $\mathrm{Ca}$ and $\mathrm{Mg}$ in river water throughout the catchment of the River Derwent in North Yorkshire. This is in spite of the fact that as the river flows across the Corallian limestone, some water is lost from the river to groundwater recharge (Carey and Chadha, 1998). The predictive models did not require land use data inputs. This was as anticipated from the hypothesis that stream water sediment composition would reflect all aspects of the riparian zone soil system, including land use effects. Further work is needed, however, to robustly account for the poorer linear relationships observed for Mg concentration.

Attempts to predict minimum values for $\mathrm{Ca}$ and alkalinity using a simple regression approach were, however, slightly less encouraging, which was thought to be primarily due to variations in hydrological response times to individual storm events across the catchment.

\section{Acknowledgements}

We are indebted to the Environment Agency for the provision of analytical data for the River Derwent, and to the Commonwealth Scholarships Commission for financial support for the principal author.

\section{References}

Asano Y, Uchida T. Quantifying the role of forest soil and bedrock in the acid neutralization of surface water in steep hillslopes. Environ Pollut 2005; 133:467-80. 
Aston SR, Thornton I, Webb JS, Purves JB, Milford BL. Stream sediment composition: An aid to water quality assessment. Water Air Soil Pollut 1974; 3:321-5.

BGS, 1996. British Geological Survey Regional Geochemistry: North-East England. BGS, Keyworth, UK. vii + 100 pp.

Bennett DA. A framework for the integration of geographical information systems and model base management. Int J Geog Inf Sci 1997; 11:337-57.

Billett MF, Cresser MS. Predicting streamwater quality using catchment and soil characteristics. Environ Pollut 1992; 77:263-8.

Bricker OP, Rice KC. Acidic deposition of streams - a geology-based method predicts their sensitivity. Environ Sci Technol 1989; 23:379-85.

Carey MA, Chadha D. Modelling the hydraulic relationship between the River Derwent and the Corallian Limestone aquifer. Q J Eng Geol Hydroge 1998; 31:63-72.

Christopherson N, Clair TA., Driscoll CT, Jeffries DS, Neal C, Semkin RG. Hydrochemical studies, In: Moldan B, Cerny K, editors. Scope No. 51. Biogeochemistry of Small Catchments: A Tool for Environmental Research. John Wiley \& Sons, Chichester, UK; 1994. p. 285-97.

Christopherson N, Seip HM, Wright RF. A model for streamwater chemistry at Birkenes, Norway. Water Res Res 1982; 18:977-96.

Coroza O, Evans D, Bishop I. Enhancing runoff modeling with GIS. Landscape Urban Plan 1997; 38:13-23.

Cosby BJ, Wright RF, Hornberger GM, Galloway JN. Modelling the effects of acid deposition: Assessment of a lumped parameter model of soil water and streamwater chemistry. Water Res Res 1985; 21:51-63.

Cowen DJ, Jensen JR, Bresnahan PJ, Ehler GB, Graves D, Huang X, Wiesner C, Mackey HE. The design and implementation of an integrated geographic information system for environmental applications. Photogramm Eng Rem Sens 1995; 61:1393-404. 
Cresser MS, Smart R, Billett MF, Soulsby C, Neal C, Wade A, Langan S, Edwards AC. Modelling water chemistry for a major Scottish river from catchment attributes. J Appl Ecol 2000; 37 (Supplement 1):171-84.

Cresser MS, Ahmed N, Smart RP, Arowolo T, Calver LJ, Chapman PJ. Predicting Gran alkalinity and calcium concentrations in river waters over a national scale using a novel modification to the G-BASH model. Environ Pollut 2006; 143:361-6.

Darnley AG, Björklund A, Bølviken B, Gustavsson N, Koval PV, Plant JA, Steenfett A, Tauchid M, Xuejing Xie. A global geochemical database for environmental and resource management: recommendations for international geochemical mapping. Final report of IGCP Project 259. IUNESCO Publishing, Ottawa; 1995.

Djokic D, Maidment DR. Application of GIS network routines for water flow and transport. J Water Res Pl-Asce 1993; 119:229-45.

Gherini SA, Mok L, Hudson RJM, Davis GF, Chen CW, Goldstein RA. The ILWAS model: formulation and application. Water Air Soil Pollut 1985; 26:425-60.

Goodchild MF, Parks BO, Steyaert LT. Environmental modeling with GIS. Oxford University Press, New York; 1993.

Green SM, Machin R, Cresser MS. Effect of long-term changes in soil chemistry induced by road salt applications on $\mathrm{N}$-transformations in roadside soils. Environ Pollut 2008; 152:20-31.

Greene RG, Cruise JF. Urban watershed modeling using geographic information system. J Water Res Pl-Asce 1995; 121:318-25.

Hawkins CP, Olson JR, Hill RA. The reference condition: Predicting benchmarks for ecological and water-quality assessments. J N Am Benthol Soc 2010; 29:312-43.

Hooper RP, Aulenbach BT, Burns DA, McDonnell J, Freer J, Kendall C, Beven K. Riparian control of stream-water chemistry: implications for hydrochemical basin models. In: Haigh MJ, Krecek J, Rajwar GS, Kilmartin MP, editors. Hydrology, Water Resources and Ecology in Headwaters. Proceedings of the 
Headwater '98 Conference at Meran/Merano, Italy, April 1998. IAHS Publications No. 248. IAHS, Oxford, UK; 1998. p. 451-8.

Johnson LB, Richards C, Host GE, Arthur JW. Landscape influences on water chemistry in Midwestern stream ecosystems. Freshwater Biol 1997; 37:193208.

Merchant JW. GIS-based groundwater pollution hazard assessment: a critical review of the DRASTIC model. Photogramm Eng Rem Sens 1994; 60:111727.

Moldan B, Cerny K. Biogeochemistry of small catchments. A Tool for Environmental Research. Wiley, Chichester, England; 1994. 419 pp.

Neal C. Alkalinity measurements within natural waters: towards a standardised approach. Sci Total Environ 2001; 265:110-5.

Neal C, Robson AJ, Wass P, Wade AJ, Ryland GP, Leach DV, Leeks GJL 1998. Major, minor, trace element and suspended sediment variations in the River Derwent. Sci Total Environ 1998; 210/211:163-72.

Nikolaidis NP, Rajaram H, Schnoor JL, Georgakakos KP. A generalized soft water acidification model. Water Res Res 1988; 24:1983-96.

Norton SA 1980. Atmospheric sulphur deposition. Geologic factors controlling the sensitivity of aquatic ecosystems to acid precipitation. In: Shriner DS, Richmond CR, Lindberg SE, editors. Proceedings of the $2^{\text {nd }}$ Life Sciences Symposium on Potential Environmental and Health Consequences of Atmospheric Sulfur Deposition. Ann Arbor Science Publishers, Michigan, p 521-31.

NRA. River Derwent Catchment Management Plan: Consultation Report. Northumbria and Yorkshire Area: National Rivers Authority; 1992. 97 pp.

Plant J, Moore PJ. Regional geochemical mapping and interpretation in Britain. Phil Trans Royal Soc Lond. 1979; B 288:95-112.

Poiani KA, Bedford BL. GIS-based nonpoint source pollution modeling: Considerations for wetlands. J Soil Water Conserv 1995; 50:613-19. 
Ross MA, Tara OD. Integrated hydrologic modeling with geographic information systems. J Water Res Pl-Asce 1993; 119:129-40.

Rothwell JJ, Dise NB, Taylor KG, Allott TEH, Scholefield P, Davies H, Neal C. A spatial and seasonal assessment of river water chemistry across North West England. Sci Total Environ 2010; 408:841-55.

Shamsi UM. Storm-water management implementation through modeling and GIS. J Water Res Pl-Asce 1996; 122:114-27.

Smart RP, Soulsby C, Cresser MS, Wade AJ, Townend J, Billett MF, Lagan S. Riparian zone influence on stream water chemistry at different spatial scales: a GIS-based modelling approach, an example for the Dee, NE Scotland. Sci Total Environ 2001; 280:173-93.

Smith MB, Vidmar A. Data set derivation for GIS-based urban hydrological Modeling. Photogramm Eng Rem Sens 1994; 60:67-76.

Smith RI, Cape JN, Binnie J, Murray TD, Young M, Fowler D. Deposition of atmospheric pollutants to the LOIS area. Sci Total Environ 1997; 194/195:7186.

Soulsby C, Reynolds B. Impact of source area liming on the hydrochemistry of an acidic headwater stream in upland Wales. In: McGregor DFM, Thompson DA, editors. Geomorphology and Land Management in a Changing Environment. Wiley, Chichester; 1995. p. 121-37.

Sui DZ, Maggio RC. Integrating GIS with hydrological modeling: practices, problems, and prospects. Comput Environ Urban 1999; 23:33-51.

Tetzlaff D, Waldron S, Brewer MJ, Soulsby C. Assessing nested hydrological and hydrochemical behaviour of a mesoscale catchment using continuous tracer data. J Hydrol 2007; 336:430-43.

USEPA. Better assessment science integrating point and nonpoint sources. Washington, DC: U.S. Environmental Protection Agency. EPA-823-B-01-001, http://www.epa.gov/OST/BASINS, 2001.

Wade AJ, Neal C, Soulsby C, Smart RP, Langan SJ, Cresser MS. Modelling streamwater quality under varying hydrological conditions at different spatial scales. J Hydrol 1999; 217:266-83. 
Whitehead PG, Reynolds B, Hornung M, Neal C, Cosby J, Parios P. Modelling long-term stream acidification trends in upland Wales at Plynlimon. Hydrol Process 1988; 2:357-68. 
Table.1.

\begin{tabular}{lrrrrrrrrrrrr}
\hline & \multicolumn{4}{c}{ Ca (mg/l) } & \multicolumn{4}{c}{ Mg (mg/l) } & \multicolumn{4}{c}{ Alkalinity (as CaCO3 mg/l) } \\
Sample Point & Max & Min & Mean & SD & Max & Min & Mean & SD & Max & Min & Mean & SD \\
\hline Forge Valley & 70.9 & 19.8 & 50.7 & $(12.7)$ & 6.21 & 2.68 & 4.9 & $(0.8)$ & 144 & 29.8 & 96.6 & $(28.5)$ \\
Sherburn & 147 & 67.7 & 109 & $(16.2)$ & 22.8 & 7.62 & 12.3 & $(2.3)$ & 225 & 95.5 & 172.1 & $(27.6)$ \\
Yedingham & 149 & 84 & 122 & $(12.4)$ & 15.2 & 8.77 & 11.5 & $(1.3)$ & 234 & 121 & 197 & $(23.3)$ \\
Malton & 101 & 20.3 & 82.3 & $(14.7)$ & 8.3 & 2 & 6.7 & $(1.1)$ & 191 & 21.8 & 150 & $(30.3)$ \\
Low Hutton & 98.7 & 20.6 & 82.5 & $(14.0)$ & 8.32 & 1.92 & 6.7 & $(1.1)$ & 224 & 20.6 & 152 & $(30.0)$ \\
Howsham & & & & & & & & & & & & \\
Bridge & 101 & 28.5 & 81.6 & $(14.9)$ & 8.41 & 2.61 & 6.6 & $(1.2)$ & 194 & 47.6 & 149 & $(30.2)$ \\
Sutton Lock & 106 & 26.1 & 84.1 & $(15.6)$ & 9.15 & 2.71 & 7.2 & $(1.3)$ & 192 & 28.2 & 149 & $(32.4)$ \\
Derwent Bridge & 125 & 36.3 & 89.1 & $(15.9)$ & 10.5 & 3.52 & 8.0 & $(1.4)$ & 207 & 50.4 & 156 & $(30.4)$
\end{tabular}

Table.2. Ranges of Ca and Mg in River Water Sediments.

\begin{tabular}{lrrrr} 
& \multicolumn{4}{c}{ Range } \\
\cline { 2 - 5 } & Lowest & \multicolumn{1}{c}{ Highest } & \multicolumn{1}{c}{ Mean } & \multicolumn{1}{l}{ SD } \\
\cline { 2 - 5 } Ca & 2024.4 & 164204.4 & 17723.6 & $(23745.8)$ \\
Mg & 1073.9 & 43164.4 & 5756.8 & $(5072.4)$
\end{tabular}


Table 2. Ranges and means of $\mathrm{Ca}$ and Mg concentrations (\%) in river sediments.

\begin{tabular}{|l|c|c|c|c|}
\hline Element & Lowest & Highest & Mean & SD \\
\hline Ca & 0.202 & 16.42 & 1.77 & $(2.37)$ \\
\hline Mg & 0.107 & 4.32 & 0.576 & $(0.507)$ \\
\hline
\end{tabular}

\begin{tabular}{|c|c|c|c|c|c|c|c|c|c|c|}
\hline $\begin{array}{c}\text { Fig. } \\
\text { No. }\end{array}$ & $\begin{array}{c}\text { Dependent } \\
\text { (water) } \\
\text { variable }\end{array}$ & $\begin{array}{c}+/- \\
\text { Forge } \\
\text { Valley }\end{array}$ & $\begin{array}{c}\text { Independent } \\
\text { (sediment) } \\
\text { variable }\end{array}$ & \multicolumn{3}{|c|}{ Slope } & \multicolumn{3}{|c|}{ Intercept } & $\mathbf{R}^{2}$ \\
\hline & & & & Value & SE & t & Value & SE & t & \\
\hline 2 & $\begin{array}{c}\text { Mean } \\
\text { alkalinity }\end{array}$ & - & $\begin{array}{c}\mathrm{Ca}+\mathrm{mg} \\
\left.\mathrm{mmol}_{\mathrm{c}} / \mathrm{kg}\right) \\
\mathrm{x}^{2}\end{array}$ & .0000151 & .000 & 13.804 & 112.778 & 3.668 & 30.744 & 0.974 \\
\hline 2 & $\begin{array}{c}\text { Mean } \\
\text { alkalinity }\end{array}$ & - & $\begin{array}{c}\mathrm{Ca}+\mathrm{mg} \\
\left(\mathrm{mmol}_{\mathrm{c}} / \mathrm{kg}\right) \mathrm{x}\end{array}$ & .057 & .005 & 10.485 & 60.478 & 9.679 & 6.248 & 0.956 \\
\hline 3 & Mean Mg & + & $\mathrm{Mg} \mathrm{( \% ) \textrm {x } ^ { 2 }}$ & 14.141 & 1.398 & 10.112 & 2.438 & .596 & 4.092 & 0.945 \\
\hline 3 & Mean Mg & + & $\mathrm{Mg}(\%) \mathrm{x}$ & 16.614 & 2.427 & 6.845 & -2.172 & 1.521 & -1.428 & 0.886 \\
\hline
\end{tabular}




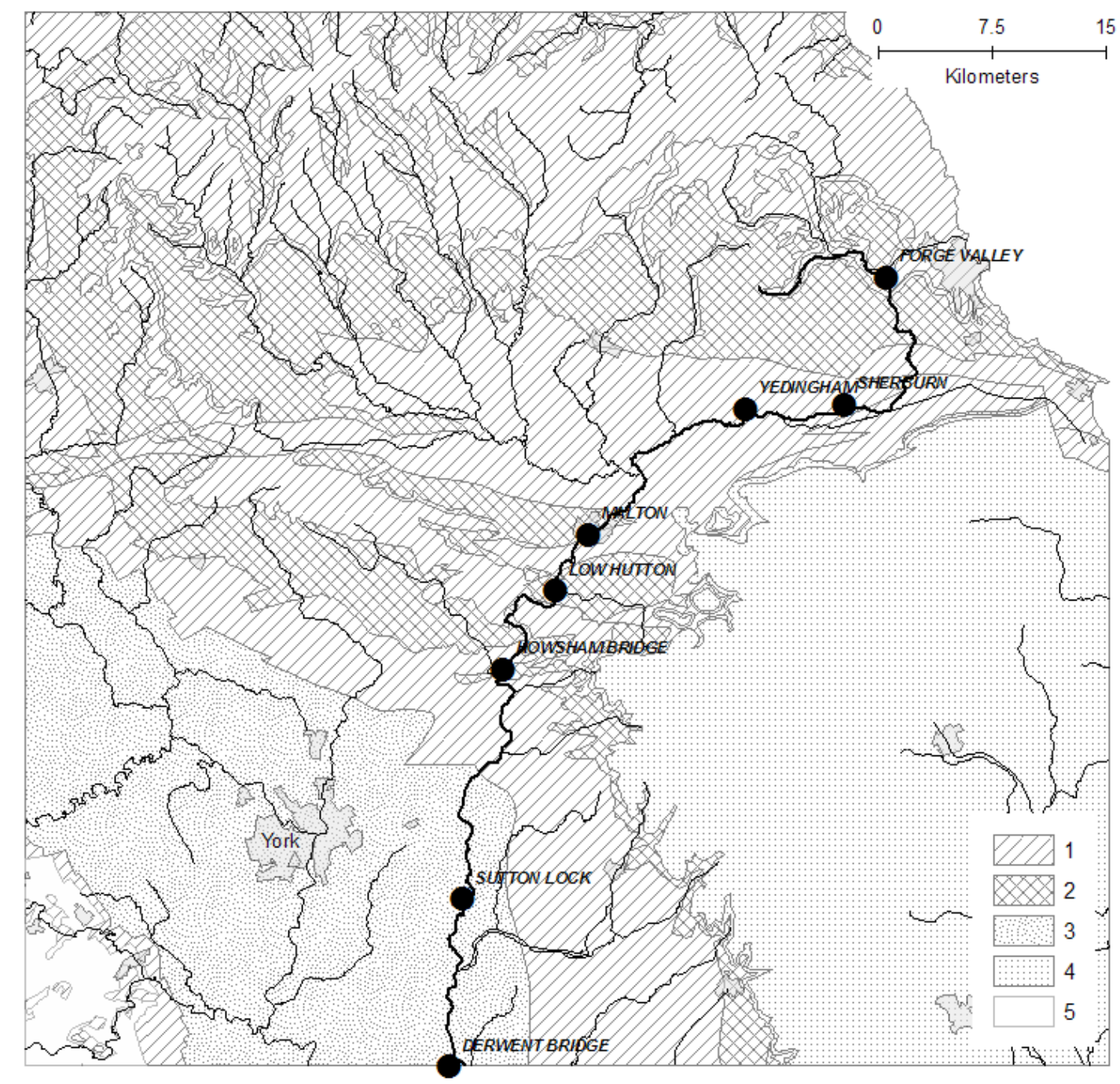

Fig. 1. Simplified bedrock geology around the sampling sites and the distribution of the eight monitoring sites (circles) along the length of the River Derwent (darker line) in North Yorkshire. Geology data are reproduced with the permission of the British Geological Survey @NERC. All rights reserved. In the key, 1 denotes Mudstones, siltstones and sandstones; 2 Sequences including limestones and associated, mudstones, siltstones and sandstones; 3 Sandstones and conglomerates; 4 Chalk; 5 Miscellaneous other (5 is all outside the Derwent catchment area). 

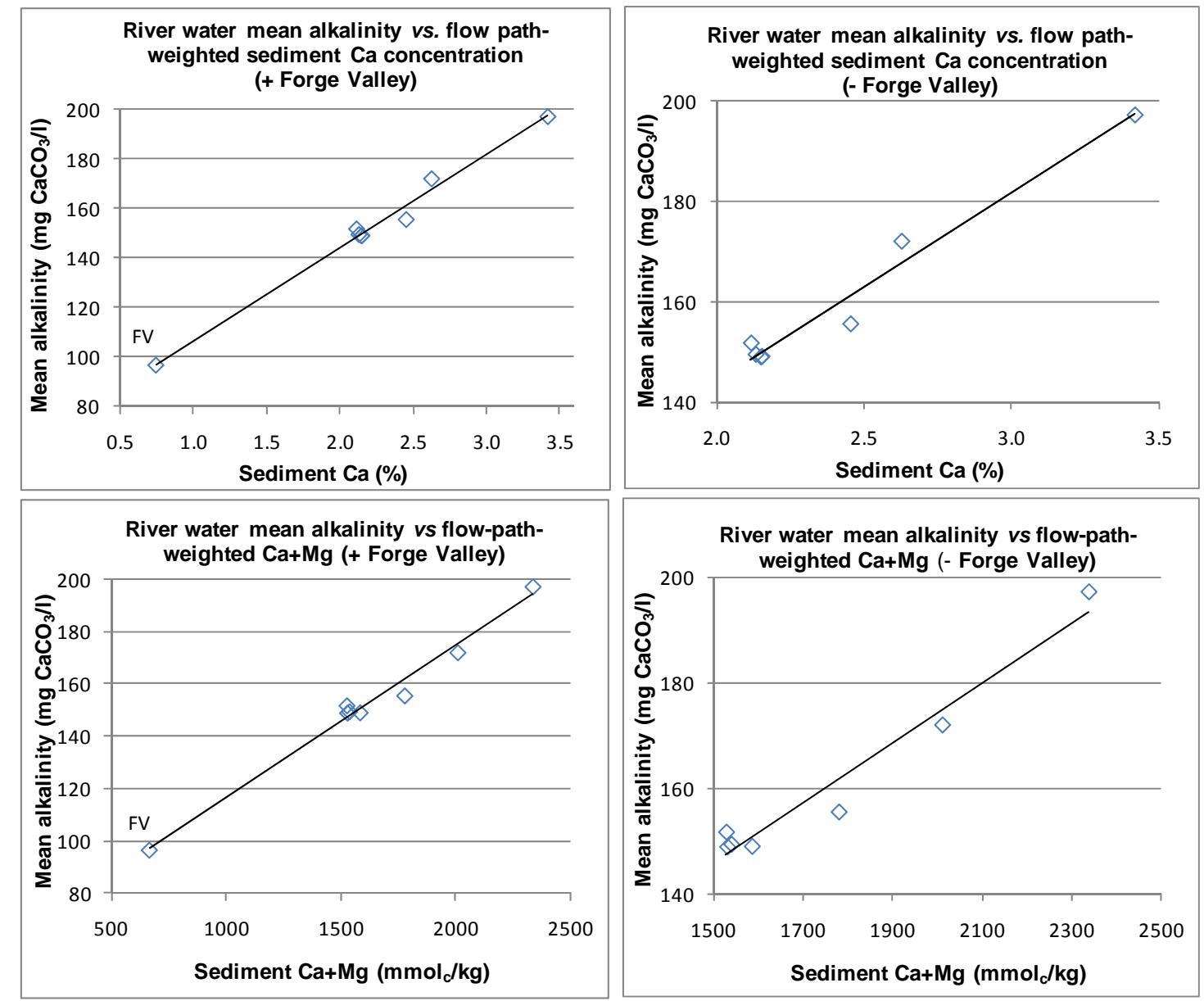

Fig. 2. Linear correlations of mean river water alkalinity with flow-path-weighted Ca concentration (\%) in sediment, +/- Forge Valley data (upper left and right respectively), and with flow path-weighted $\mathrm{Ca}+\mathrm{Mg}$ concentrations in sediment $\left(\mathrm{mmol}_{\mathrm{C}} / \mathrm{kg}\right)$ (centre left and right respectively). "FV" denotes the Forge Valley points. 

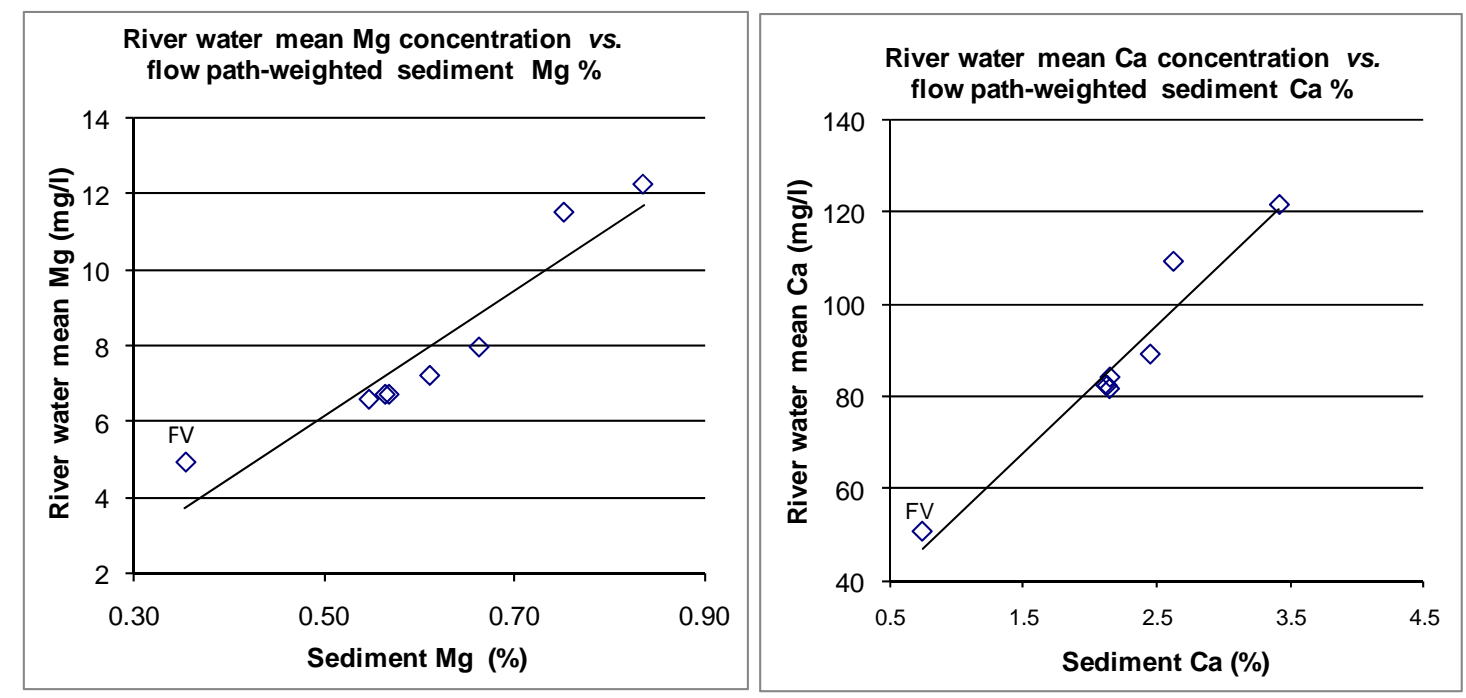

Fig. 3. River water mean $\mathrm{Mg}$ (left) and $\mathrm{Ca}$ (right) concentration vs. flow pathweighted sediment \% Mg or \% Ca concentration respectively (both including Forge Valley values, denoted by FV). 

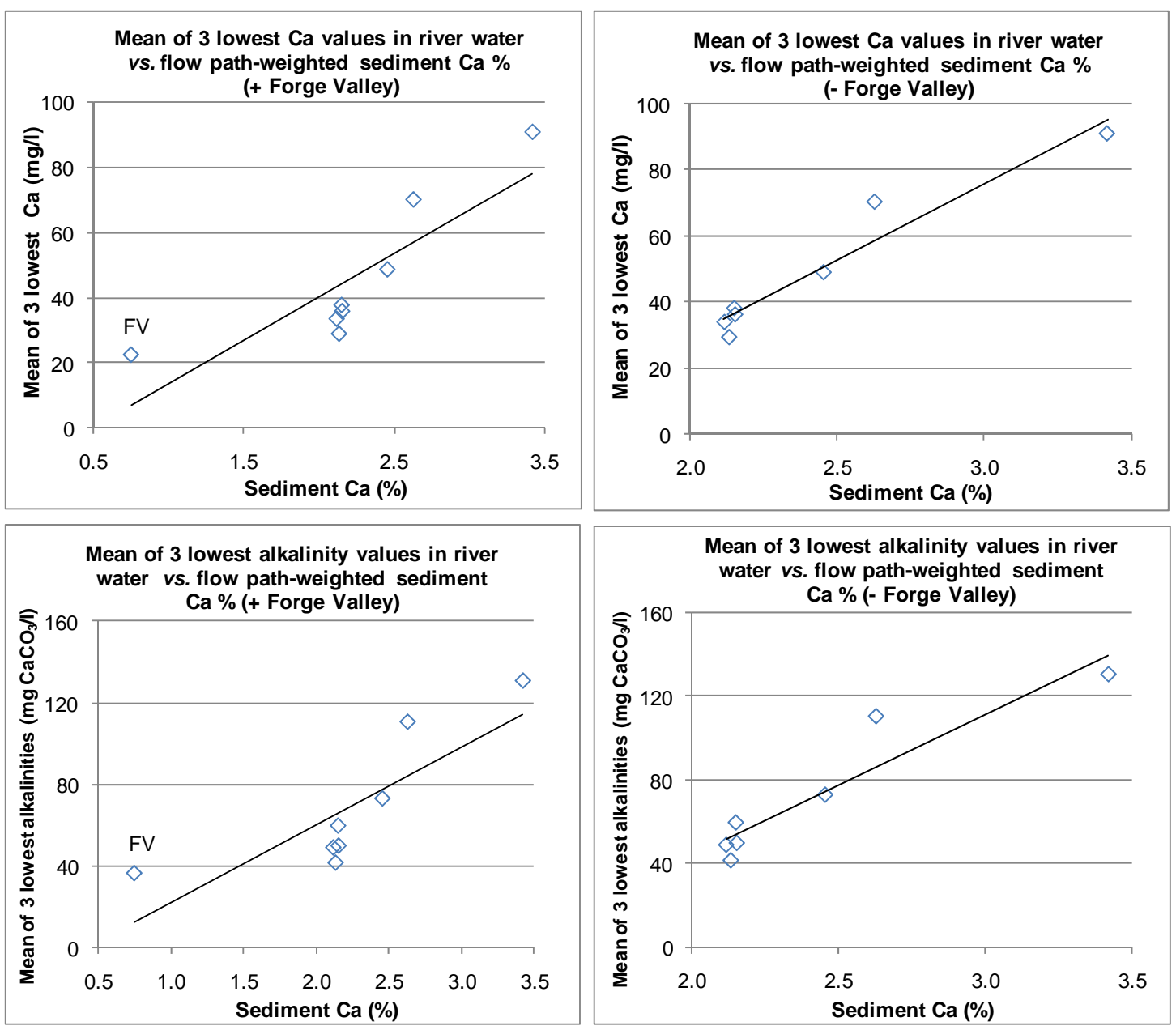

Fig. 4. Correlations of means of three lowest $\mathrm{Ca}$ concentrations in river water (upper plots) and alkalinity in river water (lower plots) with flow path-weighted sediment Ca concentration in sediment (\%), with (left) and without (right) Forge Valley data, denoted by FV. 